\title{
Genetic Variants and Haplotypes in the IL10 Gene and Their Association with Opportunistic Infections among HIV-Infected Patients in Korea in the Era of Highly Active Antiretroviral Therapy
}

\author{
In-Suk Kim¹, Hyung-Hoi Kim², Chulhun L. Chang ${ }^{1}$ \\ ${ }^{1}$ Department of Laboratory Medicine and Research Institute for Convergence of Biomedical Science and \\ Technology, Pusan National University Yangsan Hospital, Pusan National University School of Medicine, \\ ${ }^{2}$ Department of Laboratory Medicine and Biomedical Research Institute, Pusan National University Hospital, \\ Pusan National University School of Medicine, Busan, Korea
}

Background: Genetic variants and haplotypes of the interleukin-10 (IL10) gene have been shown to affect clinical outcomes, including the incidence of opportunistic infections (OIs), in HIV-infected patients. This study investigated the effect of IL10 gene variants on susceptibility to Ols in HIV-infected Korean patients in the era of highly active antiretroviral therapy (HAART). Methods: Eighty-five HIV-infected patients receiving HAART were enrolled in the study. Ols were diagnosed based on the published criteria of the Korean Society for AIDS. Three promoter SNPs and four haplotype-tagging SNPs (htSNPs) of IL10 were selected and genotyped. The haplotypes were reconstructed according to the genotyping data and linkage disequilibrium (LD) status of these SNPs. Results: During the study, 38 Ols developed in 23 of the 85 patients $(27.1 \%)$, at a rate of 1.7 episodes/ patient. Carrying the minor alleles at the rs 1518111 , rs3024490, and rs1800871 SNPs had a protective ef- fect against Ols (adjusted $P=0.035$ ). Among the seven assessed variants, only three possible haplotypes were observed. The second most common haplotype, which was composed of the rs1518111 minor allele and the rs3021094 major allele showed a protective effect against Ols $(P=0.0153)$.

Conclusion: This study demonstrated that some IL10 genetic variants and haplotypes are associated with protective effects against Ols in the era of HAART. These data suggest the potential of two htSNPs, rs1518111 and rs3021094, as markers revealing the genetic association of IL10 in Koreans. This is the first report on the association of $I L 10$ with Ols in HIV-infected Korean patients in the era of HAART. (Ann Clin Microbiol 2019;22:14-22)

Key Words: Haplotype, HIV, IL10, Opportunistic infections, Susceptibility

\section{INTRODUCTION}

The development of highly active antiretroviral therapy (HAART), especially after 1995, has significantly modified the course of HIV disease and substantially reduced the occurrence of opportunistic infections (OIs) and mortality in patients with HIV $[1,2]$. The beneficial effects of HAART result from a gradual restoration of pathogen-specific immune responses, mediated by suppression of HIV-1 replication and an increase in the CD4 cell count. Despite great efforts in the diagnosis and treatment of HIV infection before patients develop advanced disease, OIs continue to occur in the era of effective HAART [3]. Factors associated with an increased risk of OIs include a low CD4 cell count $\left(<200 / \mathrm{mm}^{3}\right)$ at the time of HIV diagnosis, injection drug use, older age, and high HIV RNA copy numbers $(>10,000$ copies/mL) [2,4-6].

Interleukin-10 (IL10) has been associated with the progression of HIV infection to AIDS [7-12]; however, its role has not been

Received 10 August, 2018, Revised 21 November, 2018, Accepted 22 November, 2018

Correspondence: In-Suk Kim, Department of Laboratory Medicine, Pusan National University Yangsan Hospital, Pusan National University School of Medicine, 20 Geumo-ro, Mulgeum-eup, Yangsan 50612, Korea. (Tel) 82-55-360-1870, (Fax) 82-55-360-1880, (E-mail) iskim0710@gmail.com

(c) The Korean Society of Clinical Microbiology.

(․) This is an Open Access article distributed under the terms of the Creative Commons Attribution Non-Commercial License (http://creativecommons.org/licenses/by-nc/4.0) which permits unrestricted non-commercial use, distribution, and reproduction in any medium, provided the original work is properly cited. 
clearly defined. IL10 is a pleiotropic cytokine involved in diverse anti-inflammatory and immunosuppressive activities, including inhibition of cytokine production by macrophages and inhibition of their accessory functions during $\mathrm{T}$ cell activation [13]. In the immune system, IL10 functions to suppress the inflammatory response [14]. Previous studies have mainly focused on the three classic single nucleotide polymorphisms (SNPs) located in the proximal promoter region of the ILIO gene, rs1800896, rs1800871, and rs1800872, at positions - 1082 [G/A], -819 [C/T], and -592 [C/A], respectively [7-12]. Some IL10 variants are associated with differential IL10 production and exacerbation of immune dysfunction in HIV-infected patients $[7,9,12]$.

Considering that access to HAART and optimization of antiretroviral treatment options have not been uniform among the HIV-infected population across genetic variants of IL10, investigation of genetic susceptibility to HIV-related OIs in the era of HAART might be necessary. Here, we provide a comprehensive analysis of the association between genetic variants and haplotypes of ILIO and OIs among HIV-infected Korean patients in the era of HAART.

\section{MATERIALS AND METHODS}

\section{Patient selection and clinical data acquisition}

A total of 120 patients diagnosed as HIV-infected and treated with HAART at Pusan National University Hospital from May 2011 to Feb 2012 were preliminarily recruited based on residual specimens and clinical information donated to the biobank. Finally, a total of 85 patients, for whom a retrospective review of electronic medical records and residual EDTA blood were available, were enrolled in the study.

OIs were diagnosed based on clinical, laboratory, and pathological findings, according to published criteria [15]. A diagnosis of tuberculosis (TB) was based on compatible symptoms/signs, a positive acid-fast bacilli smear, culture, polymerase chain reaction (PCR), and histological or radiological findings compatible with TB. Pneumocystis jirovecii pneumonia was diagnosed based on either compatible symptoms/signs; radiological findings, such as bilateral, diffuse interstitial infiltrates; demonstration of a cyst wall on methenamine silver staining; or a positive Pneumocystis jirovecii PCR. Cytomegalovirus (CMV) viremia was detected by a CMV-specific PCR assay. CMV retinitis was diagnosed by an ophthalmologist. CMV disease, such as pneumonia or hepatitis, was diagnosed based on compatible symptoms and pathology staining for CMV.

The demographic and clinical data of all patients were obtained from a retrospective review of electronic medical records (Table 1). The acquired data included gender, age, complete blood cell counts, CD4 $\mathrm{T}$ cell count at initiation of HAART, the treatment regimen, and OIs occurring during follow up.

Table 1. Demographic and clinical characteristics of patients with and without opportunistic infections

\begin{tabular}{|c|c|c|c|c|}
\hline Characteristics & Total $(n=85)$ & OIs $(+)(n=23)$ & OIs $(-)(n=62)$ & $P$ value \\
\hline Age, y $($ mean \pm SD $)$ & $46.9 \pm 11.9$ & $53.3 \pm 11.5$ & $44.6 \pm 11.2$ & 0.002 \\
\hline Age group, n (\%) & & & & 0.047 \\
\hline$<40$ & $28(32.9)$ & $5(21.7)$ & $23(37.1)$ & \\
\hline $40-60$ & $47(55.3)$ & $12(52.2)$ & $35(56.5)$ & \\
\hline$\geq 60$ & $10(11.8)$ & $6(26.1)$ & $4(6.5)$ & \\
\hline Male sex, $\mathrm{n}(\%)$ & $73(85.9)$ & $21(91.3)$ & $52(83.9)$ & 0.499 \\
\hline $\mathrm{CD} 4 \mathrm{~T}$ cell count at initiation of HAART, cell $/ \mathrm{mm}^{3}($ mean $\pm \mathrm{SD})$ & $165 \pm 134$ & $94 \pm 100$ & $196 \pm 136$ & 0.007 \\
\hline CD4 $\mathrm{T}$ cell count after 1 year of HAART, cell $/ \mathrm{mm}^{3}($ mean $\pm \mathrm{SD})$ & $285 \pm 211$ & $175 \pm 139$ & $331 \pm 220$ & 0.009 \\
\hline \multicolumn{5}{|l|}{ Opportunistic infection subtype } \\
\hline Tuberculosis, n (\%) & $12(14.1)$ & $12(52.2)$ & & \\
\hline Candidiasis, $\mathrm{n}(\%)$ & $10(11.8)$ & $10(43.5)$ & & \\
\hline Pneumocystis jirovecii pneumonia, n (\%) & $8(9.4)$ & $8(34.8)$ & & \\
\hline CMV infection, $\mathrm{n}(\%)$ & $3(3.5)$ & $3(13.0)$ & & \\
\hline Cryptococcosis, n (\%) & $2(2.4)$ & $2(8.7)$ & & \\
\hline Other, $\mathrm{n}(\%)^{*}$ & $3(3.5)$ & $3(13.0)$ & & \\
\hline
\end{tabular}

*Other opportunistic infections included herpes zoster and herpes simplex infection and toxoplasmosis.

Abbreviations: OI, opportunistic infection; HAART, highly active antiretroviral therapy; CMV, cytomegalovirus. 


\section{Selection and genotyping of the $I L 10$ variants}

We used a two-step approach to select relevant genetic variants and assess the genetic variation in the ILIO gene. First, we chose commonly studied variants that have been identified in the literature and reported to be associated with HIV disease progression and mortality. Most studies have focused on three promotor variants in the proximal region of gene, rs1800896, rs1800871, and rs1800872 [7,9,12,16,17].

Second, we added haplotype-tagging SNPs (htSNPs) to ensure good marker coverage for haplotype reconstruction and to increase the analytic efficiency [18]. Four additional SNPs were chosen from a public database (the International HapMap Project, Phase II data; available at http://www.ncbi.nih.gov/ and http://www.hapmap.org/) [19]. Using the algorithm-Tagger-pairwise method to analyze the data, only htSNPs with a minor allele frequency $>10 \%$ were considered, and the threshold for pairwise linkage disequilibrium (LD) was set as a squared correlation coefficient $\left(\mathrm{r}^{2}\right)>0.8$. Finally, seven SNPs, including three promotor SNPs and four intronic htSNPs, in the IL10 gene (Table 2) were genotyped.

The DNA samples were genotyped using matrix-assisted laser desorption/ionization time of flight mass spectrometry (Sequenom, Inc., San Diego, CA, USA) [20]. For each SNP, the genotype was confirmed by two independent scorers. We used 12 quality control samples for every 384-well plate assay, and none failed. In addition, re-genotyping of $5 \%$ of the study samples resulted in more than $99 \%$ concordance. Hardy-Weinberg equilibrium testing was performed to ensure that each marker was in equilibrium [21], and the success rate of each assay was $>99 \%$.

\section{Haplotype analyses}

Pairwise measures of LD, as measured by Lewontin's co- efficient $\left(D^{\prime} ; D^{\prime}=D / D_{\max }\right)$ and $r^{2}$, between the variants that were genotyped, were calculated with Haploview version 4.2 (Broad Institute of MIT and Harvard, Cambridge, MA, USA) [22]. The haplotype frequency estimation and association analyses were performed using Haploview 4.2. Haplotypes with a frequency $<1 \%$ were not considered in the analysis.

\section{Statistical analysis}

We applied Pearson's chi-square or Fisher's exact test (for numbers $<5$ ) to compare categorical variables between patients with and without OIs. The Mann-Whitney $U$ test was used to compare continuous variables between subgroups.

We determined whether the allelic distribution of the seven variants was in Hardy-Weinberg equilibrium by the chi-square test. The allele and genotype frequencies of these SNPs were compared between patients with and without OIs by the chi-square or Fisher's exact test. Unconditional logistic regression was used to estimate the odds ratios (ORs) and 95\% confidence intervals (CIs) of the association between individual variants and OIs using three models of phenotypic expression (additive, dominant, and recessive). All association analyses were adjusted for age at the initiation of HAART ( $<40,40-60$, and $\geq 60 \mathrm{y}$ ) and gender as possible confounding factors. Adjusted $P$ value was expressed by Bonferroni correction.

We investigated the possible interactions between haplotypes and OIs and tested the main effects of a single locus or haplotype while adjusting for multiple testing based on the permutation step-down procedure using Haploview [22]. For the permutation testing, the frequencies of single markers and haplotypes in this block were compared (i.e., "the Single Markers and Haplotypes in Blocks" option was used). Ten million permutations were performed.

The $P$ values reported in this study were calculated by

Table 2. Selected variants and minor allele frequencies in the ILI0 gene based on GRCh37.p13

\begin{tabular}{|c|c|c|c|c|c|c|c|c|c|}
\hline $\begin{array}{l}\text { Reference } \\
\text { SNP ID }\end{array}$ & $\begin{array}{l}\text { Chromosome } \\
\text { position }\end{array}$ & $\begin{array}{l}\text { Contig } \\
\text { position }\end{array}$ & $\begin{array}{c}\text { HGVS } \\
\text { nomenclature }\end{array}$ & $\begin{array}{c}\text { Observed } \\
\text { heterozygosity }\end{array}$ & $\begin{array}{c}\text { Predicted } \\
\text { heterozygosity }\end{array}$ & $P$ value ${ }^{*}$ & $\begin{array}{l}\text { Major } \\
\text { allele }\end{array}$ & $\begin{array}{c}\text { Minor } \\
\text { allele }\end{array}$ & $\begin{array}{l}\text { Minor allelic } \\
\text { frequency }\end{array}$ \\
\hline rs1554286 & $206,944,233$ & 462,012 & c. $378+19 \mathrm{~T}>\mathrm{C}$ & 0.410 & 0.426 & 0.895 & $\mathrm{~T}$ & $\mathrm{C}$ & 0.308 \\
\hline rs1518111 & $206,944,645$ & 462,424 & c. $225+56 \mathrm{~A}>\mathrm{G}$ & 0.383 & 0.422 & 0.522 & A & G & 0.302 \\
\hline rs3021094 & $206,944,952$ & 462,731 & c. $166-192 \mathrm{~A}>\mathrm{C}$ & 0.469 & 0.496 & 0.745 & $\mathrm{~A}$ & $\mathrm{C}$ & 0.457 \\
\hline rs3024490 & $206,945,311$ & 463,090 & c. $165+305 \mathrm{~T}>\mathrm{G}$ & 0.383 & 0.422 & 0.522 & $\mathrm{~T}$ & G & 0.302 \\
\hline rs1800872 & $206,946,407$ & 464,186 & c. $-592 \mathrm{~A}>\mathrm{C}$ & 0.397 & 0.421 & 0.766 & A & $\mathrm{C}$ & 0.301 \\
\hline rs1800871 & $206,946,634$ & 464,413 & c. $-819 \mathrm{~T}>\mathrm{C}$ & 0.368 & 0.400 & 0.635 & $\mathrm{~T}$ & $\mathrm{C}$ & 0.276 \\
\hline rs1800896 & $206,946,897$ & 464,676 & c. $-1082 \mathrm{~A}>\mathrm{G}$ & 0.173 & 0.158 & 1.000 & A & G & 0.086 \\
\hline
\end{tabular}

*The allele frequencies of these seven variants were in Hardy-Weinberg equilibrium in the HIV-infected patients $(n=85)$. Abbreviations: SNP, single nucleotide polymorphism; HGVS, Human genome variation society. 
two-sided probability tests, and statistical significance was set at $P<0.05$. The data were analyzed using the IBM SPSS software package, version 23 (IBM SPSS Statistics, New York, NY, USA).

\section{RESULTS}

\section{Demographic characteristics and opportunistic infections}

This study included 85 HIV-infected patients receiving HARRT (73 males and 12 females; mean age, 47 years) at a tertiary care hospital (Table 1). Among these 85 HIV-infected patients, $23(27.1 \%)$ developed 38 OIs, at a rate of 1.7 episodes/patient. Table 1 summarizes the OIs encountered in this study. TB, candidiasis, and Pneumocystis jirovecii pneumonia were the common OIs in this study.

Patients with OIs were significantly older than patients without OIs $(P=0.002)$, and they had a lower CD4 $\mathrm{T}$ cell count at initiation of HAART $(P=0.007)$ and after 1 year of HAART $(P=0.009$; Table 1).

\section{Associations between the individual variants of $I L 10$ and opportunistic infections}

Table 2 shows an overview of the selected variants used in the analyses, including the reference SNP ID, nomenclature, chromosome position, contig position, and minor allelic frequencies among the 85 HIV-infected patients. The allele frequencies of these SNPs were in Hardy-Weinberg equilibrium. The ORs of the OIs in HIV-infected patients, according to each individual SNP calculated using three models of phenotypic expression, are presented in Table 3. We detected significant association signals, suggesting a protective effect against OIs in the additive models for $\mathrm{rs} 1518111(P=0.025, \mathrm{OR}=0.361, \mathrm{CI}=0.148-0.883)$, rs3024490 $(P=0.025, \mathrm{OR}=0.361, \mathrm{CI}=0.148-0.883), \quad \mathrm{rs} 1800872$ $(P=0.042, \mathrm{OR}=0.408, \mathrm{CI}=0.172-0.967)$, and $\mathrm{rs} 1800871 \quad(P=0.035$, $\mathrm{OR}=0.357, \mathrm{CI}=0.137-0.930)$. After adjusting for age group and gender, we also detected significant associations between the minor alleles in rs1518111 (adjusted $P=0.035$, adjusted $\mathrm{OR}=0.376$, $\mathrm{CI}=0.151-0.933$ ), rs3024490 (adjusted $P=0.035$, adjusted $\mathrm{OR}=$ $0.376, \mathrm{CI}=0.151-0.933$ ), and rs 1800871 (adjusted $P=0.035$, adjusted $\mathrm{OR}=0.342, \mathrm{CI}=0.127-0.925$ ) and $\mathrm{OIs}$ in the additive models. This finding indicates that patients carrying the minor alleles in rs1518111, rs3024490, and rs1800871 had a lower risk of developing OIs.

To boost the power of association, 10-million permutation testing was performed using Haploview 4.2. The testing showed that although the minor variants of rs1518111, rs3024490, rs1800872, and rs1800871 showed a trend toward a decreased risk of OIs, they were statistically insignificant $(P=0.066,0.066$, 0.087 , and 0.066 , respectively).

Table 3. Association between individual ILIO genetic variants and opportunistic infections

\begin{tabular}{|c|c|c|c|c|c|c|c|c|c|c|}
\hline \multirow{2}{*}{ SNP ID } & \multicolumn{2}{|c|}{ Minor allele frequencies } & \multicolumn{4}{|c|}{ Additive $\left(1^{\dagger}\right.$ vs. $\left.2^{\dagger}\right)$} & \multicolumn{2}{|c|}{$\left(11^{\dagger} \begin{array}{c}\text { Dominant } \\
\left.\text { vs. } 12+22^{\dagger}\right)\end{array}\right.$} & \multicolumn{2}{|c|}{$\begin{array}{c}\text { Recessive } \\
\left(11+12^{\dagger} \text { vs. } 22^{\dagger}\right)\end{array}$} \\
\hline & OI $(+)$ & OI $(-)$ & $\begin{array}{c}\mathrm{OR} \\
(95 \% \mathrm{CI})\end{array}$ & $P$ value & Adjusted $\mathrm{OR}^{*}$ & $\begin{array}{l}\text { Adjusted } \\
P \text { value* }\end{array}$ & $\begin{array}{c}\mathrm{OR} \\
(95 \% \mathrm{CI})\end{array}$ & $P$ value & $\begin{array}{c}\mathrm{OR} \\
(95 \% \mathrm{CI})\end{array}$ & $P$ value \\
\hline rs 1554286 & 0.182 & 0.357 & $\begin{array}{c}0.466 \\
(0.203-1.073)\end{array}$ & 0.073 & $\begin{array}{c}0.498 \\
(0.214-1.159)\end{array}$ & 0.106 & $\begin{array}{c}0.522 \\
(0.195-1.398)\end{array}$ & 0.196 & NA & 0.999 \\
\hline rs 1518111 & 0.159 & 0.356 & $\begin{array}{c}0.361 \\
(0.148-0.883)\end{array}$ & 0.025 & $\begin{array}{c}0.376 \\
(0.151-0.933)\end{array}$ & 0.035 & $\begin{array}{c}0.368 \\
(0.131-1.034)\end{array}$ & 0.058 & NA & 0.999 \\
\hline rs3021094 & 0.477 & 0.432 & $\begin{array}{c}1.415 \\
(0.715-2.799)\end{array}$ & 0.319 & $\begin{array}{c}1.568 \\
(0.762-3.230)\end{array}$ & 0.222 & $\begin{array}{c}2.487 \\
(0.744-8.318)\end{array}$ & 0.139 & $\begin{array}{c}1.041 \\
(0.322-3.359)\end{array}$ & 0.947 \\
\hline rs3024490 & 0.159 & 0.356 & $\begin{array}{c}0.361 \\
(0.148-0.883)\end{array}$ & 0.025 & $\begin{array}{c}0.376 \\
(0.151-0.933)\end{array}$ & 0.035 & $\begin{array}{c}0.368 \\
(0.131-1.034)\end{array}$ & 0.058 & NA & 0.999 \\
\hline rs 1800872 & 0.159 & 0.357 & $\begin{array}{c}0.408 \\
(0.172-0.967)\end{array}$ & 0.042 & $\begin{array}{c}0.737 \\
(0.182-1.046)\end{array}$ & 0.063 & $\begin{array}{c}0.433 \\
(0.159-1.180)\end{array}$ & 0.102 & NA & 0.999 \\
\hline rs 1800871 & 0.143 & 0.327 & $\begin{array}{c}0.357 \\
(0.137-0.930)\end{array}$ & 0.035 & $\begin{array}{c}0.342 \\
(0.127-0.925)\end{array}$ & 0.035 & $\begin{array}{c}0.359 \\
(0.121-1.061)\end{array}$ & 0.064 & NA & 0.999 \\
\hline rs 1800896 & 0.023 & 0.110 & $\begin{array}{c}0.168 \\
(0.021-1.374)\end{array}$ & 0.096 & $\begin{array}{c}0.179 \\
(0.021-1.507)\end{array}$ & 0.113 & $\begin{array}{c}0.168 \\
(0.021-1.374)\end{array}$ & 0.096 & $\begin{array}{c}0.371 \\
(0.151-0.942)\end{array}$ & 0.000 \\
\hline
\end{tabular}

*ORs and $P$ values are adjusted for age at enrollment $(<40,40-60$, and $\geq 60$ y) and gender.

${ }^{\dagger} 1$ and 2 represent the major and minor alleles of the corresponding SNPs, respectively.

Abbreviations: OI, opportunistic infection; SNP, single nucleotide polymorphism; OR, odds ratio; CI, confidence interval; NA, not applicable. 


\section{Associations between the haplotypes of ILIO and opportunistic infections}

The LD maps measured by $\mathrm{D}^{\prime}$ and $\mathrm{r}^{2}$ for the seven studied SNPs are shown in Fig. 1. The seven SNPs were in complete LD $\left(\mathrm{D}^{\prime}=1.0\right)$ and highly correlated. The estimated haplotype frequencies of the IL10 SNPs in patients with and without OIs are shown in Table 4. Only three possible haplotypes were observed (haplotype frequency $>1 \%$ ), and the haplotype block was composed of six variants, with the exception of rs1800896. The reason that rs1800896 was excluded might be due to the low frequency of rs1800896 variants to make a possible haplotype frequency $>1 \%$. Each haplotype could be distinguished by only two markers, rs1518111 and rs3021094 (Table 2). Patients showing the second most common haplotype, with the minor allele of rs1518111 and the major allele of rs3021094, showed a protective effect against OIs $(P=0.0153, \quad$ OR $=0.342, \quad 95 \%$ $\mathrm{CI}=0.140-0.835)$. In the 10-million permutation testing, this haplotype showed a trend toward a decreased risk of OIs; however, it was statistically insignificant $(P=0.066)$.

\section{DISCUSSION}

This study demonstrated the genetic association of seven IL10 SNPs, including three promoter SNPs: rs1800872, rs1800871, and rs1800896 and four intronic htSNPs: rs1554286, rs1518111, rs3021094, and rs3024490, and their haplotypes with OIs in HIV-infected patients receiving HAART at a tertiary university hospital in Korea.

After adjusting for age group and gender, a significant association remained between the minor alleles of rs1518111, rs3024490, and rs1800871 and a decreased risk of OIs. Remmers et al. [23] identified a disease-associated IL10 variant (rs1518111; $\mathrm{OR}=1.45,95 \%$ CI $1.34-1.58, P=3.54 \times 10^{-18}$ ) in Behçet's disease. They also demonstrated that the major allele (A) of rs1518111 was associated with diminished mRNA expression and low protein production compared to the minor allele $(G)$, suggesting novel therapeutic targets for Behçet's disease. Our data showed that carrying the minor allele of rs 1518111 had a protective effect against OIs. This suggests that the minor allele of 1518111 leads to high level IL10 expression in regulatory T cells, helps suppress the inflammatory response, and has a protective effect against OIs.

In earlier studies, significant genetic associations were identified between ILIO and HIV infection and progression to AIDS, with individuals carrying the minor alleles of rs1800872 and rs1800896 having an increased risk for HIV infection and a faster progression to AIDS once infected in the early phase in South African, African American, and European American populations [7-12,24]. In this study, contrary to previous studies, carrying the minor allele of rs 1800872 showed a protected effect against OIs in the era of HAART. This suggests that high
A HIV-infected patients $(n=85)$

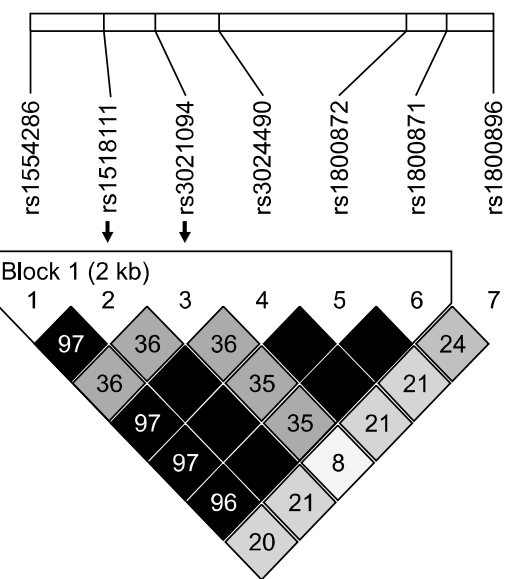

B Thep

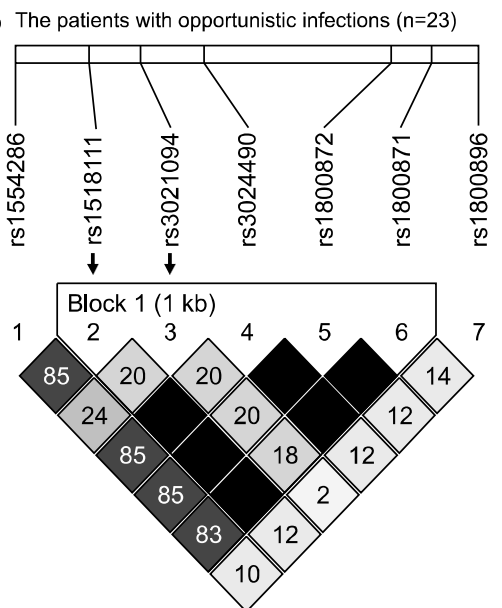

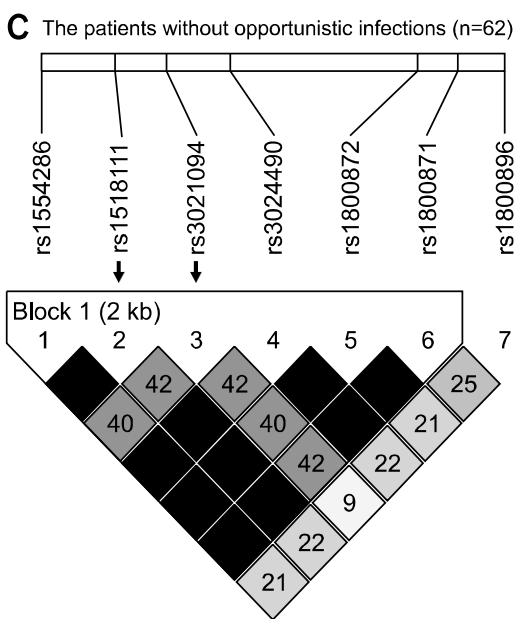

Fig. 1. Linkage disequilibrium maps of the seven variants in all HIV-infected patients (A), HIV-infected patients with opportunistic infections (B), and HIV-infected patients without opportunistic infections (C). The pairwise $\mathrm{D}^{\prime}$ and $\mathrm{r}^{2}$ values between pairs of adjacent markers were calculated with Haploview 4.2. The calculated pairwise $\mathrm{D}^{\prime}$ values of all diamonds were 1, which indicated complete linkage disequilibrium. The number in each diamond is the $\mathrm{r}^{2}$ value, which is shown in a corresponding dark gray-to-white color gradient. Diamonds without a number indicate that the $r^{2}$ value was 1 . No white colored diamonds are shown. Two haplotype tagging SNPs with rs1518111 and 3021094 distinguished each haplotype. 


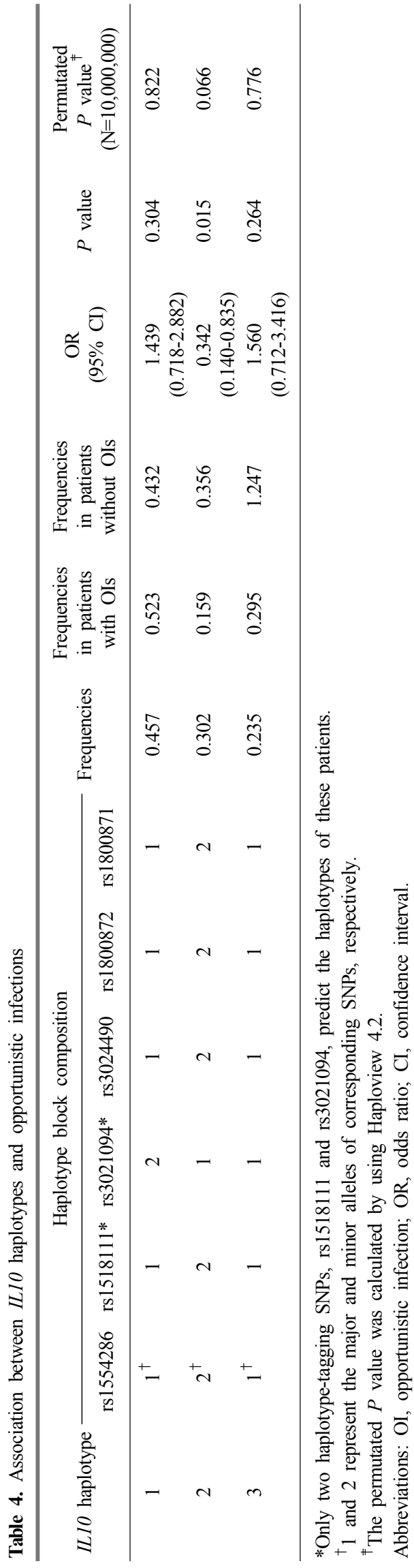

IL10 protein expression conferred by the minor allele of rs1518111 might have a dominant effect over low IL10 protein expression conferred by the minor allele of rs1800872. The decreased risk of OIs in carriers with the minor alleles of rs1518111, rs3024490, and rs1800871 might be mainly due to the high mRNA expression and high protein production conferred by the minor allele of rs1518111. This study suggests a complicated but significant role for ILIO in disease outcomes. Considering that manipulation of the IL10 pathway to boost antiviral immune responses has been suggested, there is a clear and urgent need to better understand the mechanisms underlying genetic susceptibility for this immunoregulatory cytokine.

The seven variants of ILIO showed strong LD and a single haplotype block, and only three possible haplotypes were observed in this study (Table 4). The second most common haplotype, consisting of the five minor alleles of rs1554286, rs1518111, rs3024490, rs1800872, and rs1800871 and the major allele of rs3021094, showed a protective effect against OIs $(P=0.0153)$; however, this association did not remain in 10 -million permutation testing $(P=0.066)$. Three haplotypes were divisible by six SNPs but also by only two htSNPs. In other words, two htSNPs, rs1518111 and rs3021094, could distinguish the possible haplotypes among Koreans. In contrast, the possible haplotypes in Africans and European Americans could be classified by using the classic promotor variants of rs1800872 and rs1800896 [7,9,12]. However, it was impossible to predict the haplotypes in Koreans using these classic promotor variants. Based on the international HapMap project [19], the minor allelic frequencies of rs1800896 in African, European American, Han Chinese, and Japanese populations were 0.308, $0.533,0.044$, and 0.067 , respectively. In this study, the minor allelic frequency of rs1800896 in our HIV-infected Korean population was 0.086 . In a study conducted in Thailand (Southeast Asia), the minor allelic frequency of rs1800896 was 0.063 , and three promotor SNPs of IL10 and their haplotypes were not associated with CD4+ $\mathrm{T}$ cell counts and/or viral load in 244 HIV-infected patients [16]. Previous studies of IL10 promoter haplotypes were mainly focused on the effect of rs1800896 in South Africans, African Americans, and European Americans $[7,9,12]$; however, Asians might have different haplotype distributions due to the low allelic frequencies of rs1800896. An expanded haplotype analysis using two htSNPs (rs1518111 and rs3021094) could provide more informative data for HIV-infected Korean patients. These findings will be applied in other studies of Asian populations. 
The frequency of OIs varies across countries based on genetic, environmental, and social differences. In this study, $27.1 \%$ of the HIV-infected patients developed OIs, and this incidence rate was similar to that reported in a recent Korean HIV/AIDS cohort study (24.4\%) conducted from 2006 to 2013 [5]. TB remains one of the most common OIs in Korea [5]. These data also demonstrated that a low CD4 count at initiation of therapy is an important predictor of OIs $[2,3,5,25]$. The results show that the incidence of OIs is still high in the era of HARRT, which suggests the necessity of active management and treatment. The World Health Organization recommends that HAART be started by all people with HIV infection and active TB, regardless of CD4 cell count [26].

This study had several limitations. First, the study is limited in sample size. Second, it is also possible that other operational SNPs in Koreans may track or interact with IL10. Third, we only included patient data at study enrollment; prospective longitudinal data on the incidence of OIs may be more accurate. Fourth, we did not investigate the mechanisms of cytokine level regulation. Fifth, the strong LD and fewer haplotypes among these multiple SNPs within the ILIO gene, with various potential functional effects, make it difficult to clearly identify the causal variants responsible for the phenotypic associations. Therefore, these results require additional replicates in other well-powered cohorts with well-defined clinical AIDS outcome data and experimental results.

In conclusion, this study describes several novel aspects of the genetic susceptibility of HIV-infected Korean patients to develop OIs in the era of HAART. These data demonstrate that some IL10 genetic variants, especially rs151811, and haplotypes are associated with the development of OIs and suggest the marker potential of a set of two htSNPs, rs1518111 and rs3021094, for genetic associations in Koreans. To our knowledge, this is the first report on the association of IL10 gene polymorphisms with OIs in HIV-infected Korean patients in the era of HAART.

\section{ACKNOWLEDGMENTS}

This paper was supported by Busan University's Basic Science Research Program (two year).

\section{REFERENCES}

1. Sterne JA, Hernán MA, Ledergerber B, Tilling K, Weber R, Sendi $\mathrm{P}$, et al. Long-term effectiveness of potent antiretroviral therapy in preventing AIDS and death: a prospective cohort study. Lancet
2005;366:378-84.

2. Zanoni BC and Gandhi RT. Update on opportunistic infections in the era of effective antiretroviral therapy. Infect Dis Clin North Am 2014;28:501-18.

3. WHO, UNICEF, UNAIDS, eds. Global Update on HIV Treatment 2013: Results, Impact and Opportunities. Geneva: WHO Press; 2013.

4. Manosuthi W, Chaovavanich A, Tansuphaswadikul S, Prasithsirikul $\mathrm{W}$, Inthong $\mathrm{Y}$, Chottanapund $\mathrm{S}$, et al. Incidence and risk factors of major opportunistic infections after initiation of antiretroviral therapy among advanced HIV-infected patients in a resource-limited setting. J Infect 2007;55:464-9.

5. Kim YJ, Woo JH, Kim MJ, Park DW, Song JY, Kim SW, et al. Opportunistic diseases among HIV-infected patients: a multicenternationwide Korean HIV/AIDS cohort study, 2006 to 2013. Korean J Intern Med 2016;31:953-60.

6. Mocroft A, Furrer HJ, Miro JM, Reiss P, Mussini C, Kirk O, et al. The incidence of AIDS-defining illnesses at a current CD4 count $\geq 200$ cells/ $\mu \mathrm{L}$ in the post-combination antiretroviral therapy era. Clin Infect Dis 2013;57:1038-47.

7. Naicker DD, Wang B, Losina E, Zupkosky J, Bryan S, Reddy S, et al. Association of IL-10-promoter genetic variants with the rate of CD4 T-cell loss, IL-10 plasma levels, andbreadth of cytotoxic T-cell lymphocyte response during chronic HIV-1 infection. Clin Infect Dis 2012;54:294-302.

8. Shrestha S, Wiener HW, Aissani B, Song W, Shendre A, Wilson $\mathrm{CM}$, et al. Interleukin-10 (IL-10) pathway: genetic variants and outcomes of HIV-1 infection in African American adolescents. PLoS One 2010;5:e13384.

9. Oleksyk TK, Shrestha S, Truelove AL, Goedert JJ, Donfield SM, Phair J, et al. Extended IL10 haplotypes and their association with HIV progression to AIDS. Genes Immun 2009;10:309-22.

10. Erikstrup C, Kallestrup P, Zinyama-Gutsire RB, Gomo E, Butterworth AE, Pedersen BK, et al. Reduced mortality and CD4 cell loss among carriers of the interleukin-10 -1082G allele in a Zimbabwean cohort of HIV-1-infected adults. AIDS 2007;21: 2283-91.

11. Wang C, Song W, Lobashevsky E, Wilson CM, Douglas SD, Mytilineos J, et al. Cytokine and chemokine gene polymorphisms among ethnically diverse North Americans with HIV-1 infection. J Acquir Immune Defic Syndr 2004;35:446-54.

12. Shin HD, Winkler C, Stephens JC, Bream J, Young H, Goedert JJ, et al. Genetic restriction of HIV-1 pathogenesis to AIDS by promoter alleles of IL10. Proc Natl Acad Sci U S A 2000;97: 14467-72.

13. Moore KW, de Waal Malefyt R, Coffman RL, O'Garra A. Interleukin-10 and the interleukin-10 receptor. Annu Rev Immunol 2001;19:683-765.

14. Ho AS and Moore KW. Interleukin-10 and its receptor. Ther Immunol 1994;1:173-85.

15. Korean Society for AIDS. The 2013 clinical guidelines for the diagnosis and treatment of HIV/AIDS in HIV-infected Koreans. Infect Chemother 2013;45:455-61.

16. Kingkeow D, McNicholl JM, Maneekarn N, Wongtrakul J, Taechareonkul S, Suriyanon V, et al. Frequencies of IL10 SNP genotypes by multiplex PCR-SSP and their association with viral load and CD4 counts in HIV-1-infected Thais. Asian Pac J Allergy Immunol 2011;29:94-101.

17. Smolnikova MV and Konenkov VI. Association of IL2, TNFA, IL4 and IL10 promoter gene polymorphisms with the rate of progression of the HIV infection. Russ J Immunol 2002;7:349-56.

18. Gabriel SB, Schaffner SF, Nguyen H, Moore JM, Roy J, Blumen- 
stiel B, et al. The structure of haplotype blocks in the human genome. Science 2002;296:2225-9.

19. International HapMap Consortium. The International HapMap Project. Nature 2003;426:789-96.

20. Jurinke C, van den Boom D, Cantor CR, Köster H. Automated genotyping using the DNA MassArray technology. Methods Mol Biol 2002;187:179-92.

21. Phillips MS, Lawrence R, Sachidanandam R, Morris AP, Balding DJ, Donaldson MA, et al. Chromosome-wide distribution of haplotype blocks and the role of recombination hot spots. Nat Genet 2003;33:382-7.

22. Barrett JC, Fry B, Maller J, Daly MJ. Haploview: analysis and visualization of $L D$ and haplotype maps. Bioinformatics 2005;21: 263-5.

23. Remmers EF, Cosan F, Kirino Y, Ombrello MJ, Abaci N, Satorius
$\mathrm{C}$, et al. Genome-wide association study identifies variants in the MHC class I, IL10, and IL23R-IL12RB2 regions associated with Behçet's disease. Nat Genet 2010;42:698-702.

24. Vasilescu A, Heath SC, Ivanova R, Hendel H, Do H, Mazoyer A, et al. Genomic analysis of Th1-Th2 cytokine genes in an AIDS cohort: identification of IL4 and IL10 haplotypes associated with the disease progression. Genes Immun 2003;4:441-9.

25. Wohl AR, Lu S, Turner J, Kovacs A, Witt M, Squires K, et al. Risk of opportunistic infection in the HAART era among HIV-infected Latinos born in the United States compared to Latinos born in Mexico and Central America. AIDS Patient Care STDS 2003;17:267-75.

26. WHO. Consolidated Guidelines on the Use of Antiretroviral Drugs for Treating and Preventing HIV Infection. Gevena: WHO press; 2013. 
$=$ 국문초록=

\section{고강도 항레트로바이러스 치료를 받는 한국인 HIV 환지에 있어 기회 감염과 $/ L 10$ 유전 변이와 일배체형과의 영향 분석}

${ }^{1}$ 부산대학교 의과대학 양산부산대학교병원 진단검사의학과, 의생명융합연구소,

${ }^{2}$ 부산대학교 의과대학 부산대학교병원 진단검사의학과, 의생명연구소

김인숙 ${ }^{1}$, 김형회 $^{2}$, 장철훈 ${ }^{1}$

배경: Interleukin-10 (IL10) 유전적 변이와 일배체형(haplotype)은 HIV에 감염된 환자의 기회감염을 포함한 임상 예후에 영향을 미친다. 본 연구는 고강도 항레트로바이러스 치료(highly active anti-retroviral treatment, HAART)를 받는 한국인 중 HIV에 감염된 환자의 기회감염에 대한 감수성과 IL10 유전자의 영향을 규명하고자 하였다.

방법: HAART 치료를 받는 85명의 환자를 대상으로 임상정보, 검사정보 및 병리소견을 확인하였다. 대한에이즈학회에서 제시한 기준에 따라 기회감염을 진단하였다. IL10 유전자의 promoter 부위의 단일염기변이(single nucleotide polymorphisms, SNPs)와 네 개의 haplotype-tagging SNPs (htSNPs)를 선별하여 유전형을 분석하였다. 일배체형은 유전형 자료 와 각 $\mathrm{SNP}$ 의 연관불평형(linkage disequilibrium, LD) 상태에 따라 재구성하였다.

결과: 85 명의 HIV 감염 환자 중, 23 명 $(27.1 \%)$ 의 환자에서 38 번의 기회감염이 확인되었고, 감염된 23 명의 환자에서는 1.7 회의 빈도로 기회감염이 발생하였다. rs1518111, rs3024490 및 rs1800871의 드문 대립유전자(minor allele)를 가진 경우, 기회감염에 대해 방어하는 효과를 보였다(adjusted $P=0.035$ ). 7 개의 SNPs를 통해 가능한 세 개의 일배체형이 구성되었다. rs1518111의 드문 대립유전자와 rs3021094의 흔한 대립유전자(major allele)로 구성된 두번째로 흔한 일배체형은 기회감염 에 대한 방어 효과를 보였다 $(P=0.0153)$.

결론: 본 연구는 $I L 10$ 의 유전적 변이와 일배체형이 HAART로 치료받는 HIV에 감염된 환자에서 기회감염에 대한 영향을 확인하였다. rs1518111과 rs3021094는 한국인에 있어 기회감염과 연관된 변이임을 제시할 수 있다. 본 연구는 한국인에서 최초로 HAART로 치료받는 HIV에 감염된 환자에서 IL 10 의 유전자와 기회감염과의 관계를 밝힌 것으로 생각한다. [Ann Clin Microbiol 2019;22:14-22]

교신저자 : 김인숙, 50612, 경남 양산시 물금읍 금오로 20

부산대학교 의과대학 양산부산대학교병원 진단검사의학과

Tel: 055-360-1870, Fax: 055-360-1880

E-mail: iskim0710@gmail.com 